\title{
Alih Inovasi Teknologi Dalam Peningkatan Profit Kedelai
}

\section{Transfer of Technological Innovation in Increasing Soybean Profit}

\author{
Imam Sutrisno \\ Balai Penelitian Tanaman Aneka Kacang dan Umbi
}

\section{ARTICLE INFO}

Article history:

DOI:

$10.30595 /$ pspfs.v2i.197

Submitted:

July 29, 2021

Accepted:

Sept 10, 2021

Published:

Nov 10, 2021

Keywords:

Soybean, Productivity, Farming

\begin{abstract}
The ability to increase national soybean productivity is still low. Every year the obstacle that causes farmers is it is difficult to procure quality soybean seeds and access certified seed stocks in captivity. In this condition, there needs to be a solution to support the use of quality seeds and the ease of purchasing superior/quality seeds by farmers independently and sustainably. The results of this study stated that 1) Detap 1 variety was in accordance with preferences and significantly increased soybean farming income in supporting the availability of quality consumption soybeans in East Java; 2) Gapoktan independence in preserving the Detap 1 variety with local seed farming; 3) Regional assistance by agricultural ministers and agricultural extension workers consistently as facilitators and regulators of leading technological innovations.
\end{abstract}

This work is licensed under a Creative Commons Attribution 4.0 International License.

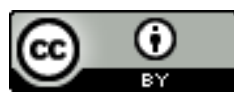

\section{Corresponding Author:}

Imam Sutrisno

Balai Penelitian Tanaman Aneka Kacang dan Umbi

J1. Raya Kendal Payak Km 8 Malang

Email: imamsutrisno71.is@gmail.com

\section{PENDAHULUAN}

Kebutuhan bahan baku kedelai untuk makanan olahan tempe dan tahu pada saat pandemi masih tinggi. Kedelai impor masih terus mendominasi di pasar karena ketersediaan maupun suplainya cukup lancar. Pelaku industri berbahan baku kedelai telah memahami kelebihan rasa kedelai lokal, namun karena mereka lebih mengedepankan kemudahan memperoleh bahan baku sehingga tetap menggunakan kedelai impor. Harga kedelai saat ini cukup baik namun petani tidak memperoleh dampak signifikan karena musim panen kedelai telah berlalu, akhirnya pelaku importir kedelai yang memperoleh keuntungan cukup tinggi (Sekarmurti et al, 2018).

Perkembangan produktivias kedelai di petani relatif rendah dari tahun ke tahun sebagai akibat rendahnya adopsi inovasi dalam penggunaan varietas unggul baru (VUB) atau varietas bersertifikasi/bermutu dan minimnya aplikasi teknologi budidaya kedelai. Permasalahan ini seperti benang kusut namun upaya mencari solusi strategi yang efektif efisien, aplikatif, fleksibel perlu komunikasi bersama antara pemerintah dan Gapoktan di wilayah sentra kedelai (Noviyanti et al, 2020). Harapan kedepan adalah kedisiplinan penggunaan bahan tanam adalah benih varietas unggul/bermutu dan adopsi teknologi budidaya kedelai, karena sudah waktunya usahatani kedelai tidak lagi dianggap usaha sampingan atau ala kadarnya supaya Indonesia tidak dijajah importir kedelai yang hanya mencari keuntungan semata (kapitalis). Petani telah banyak tahu bahwa bekas lahan kedelai mendukung performa awal pertumbuhan tanaman selanjudnya.

Tujuan penelitian ini adalah untuk memperoleh informasi respon petani dan minat adopsi varietas unggul baru/bersertifikasi sebagai bahan tanam pada musim tanam kedelai secara berkesinambungan. 


\section{METODE PENELITIAN}

Pengumpulan data sekunder (kantor Diperta serta BPS Indonesia) dan primer pada lokasi daerah sentra kedelai di kabupaten Pasuruan dan Mojokerto propinsi Jawa Timur pada tahun 2020 yang mengacu model "penelitian survey dengan melibatkan petani untuk proaktif" (Nurwanda dan Badriah, 2020) dan penelitian dengan pendekatan partisipatif (Participatory Rural Appraisal/PRA) (Ridwan et al, 2019). Dengan metode PRA, penelitian survey menggunakan kuesioner kunci (key questions) pada setiap sub topik yang dapat berkembang sesuai dengan permasalahan dan kondisi aktual, terarah, terukur untuk memperoleh data di lapang. sebagai berikut: 1) identifikasi umum dan zonasi potensial secara makro berdasarkan data sekunder sebagai informasi dan hasil penelitian yang relevan; 2) responden sasaran yaitu kelompok 'key person' antara lain: Ketua Gapoktan/Kelompok Tani, petani, penyuluh, dan yang terkait dengan penelitian; 3) identifikasi potensi masyarakat, sumberdaya lahan, permasalahan dalam peningkatan produksi kedelai. Metode penelitian diskriptif kuantitatif dengan analisis tabulasi, dan tingkat kelayakan usahatani kedelai dengan analisis $B / C$ ratio $>1$ artinya usahatani kedelai layak. Dalam menghitung tingkat nilai keuntungan usahatani dengan rumus Slovin (Kune, 2017), dibawah ini:

1. $\mathrm{TL}=\mathrm{TR}-\mathrm{TC}$

dimana :

$T L=$ Keuntungan (profit)

$T R=$ Total penerimaan usahatani (revenue)

$T C=$ Total biaya usahatani (cost)

\section{2. $\mathrm{B} / \mathrm{C}$ ratio $=\mathrm{TR} / \mathrm{TC}$}

\section{HASIL DAN PEMBAHASAN Karakteristik Petani}

Petani dari segi sosial memiliki karakter tersendiri yang akan mempengaruhi tingkat kesejahteraan maupun pergaulan sehari-hari. Petani memiliki kepedulian pada masyarakat sekitarnya dalam melakukan kehidupan di pedesaan. Usahatani dilakukan secara turun-temurun dari orang tua pada anaknya (Manyamsari dan Mujiburrahmad, 2014). Beberapa karakter petani dalam mendukung usahatani komoditas kedelai, sebagai berikut:

Tabel 1. Karakteristik petani kedelai (\%) di Pasuruan-Mojokerto Jawa Timur

\begin{tabular}{clcc}
\hline Usia & Pendidikan & $\begin{array}{c}\text { Jumlah anggota } \\
\text { keluarga } \\
\text { (orang) }\end{array}$ & $\begin{array}{c}\text { Pengalaman usahatani kedelai } \\
\text { (tahun) }\end{array}$ \\
\hline$-40-50=19 \%$ & - SD $=30 \%$ & $-1-2=11 \%$ & $-<15=61 \%$ \\
$-51-60=51 \%$ & - SMP $=41 \%$ & $-3-4=62 \%$ & $-16-30=32 \%$ \\
$-61-75=30 \%$ & - SMA $=29 \%$ & $-5-6=27 \%$ & $->31=7 \%$ \\
\hline
\end{tabular}

Pada tabel 1 menunjukkan hasil rata-rata karakteristik petani kedelai di kabupaten Pasuruan dan Mojokerto propinsi Jawa Timur. Responden dikatagorikan berdasar Usia, Tingkat pendidikan, Jumlah anggota keluarga, dan pengalaman usahatani kedelai. Petani kedelai pada usia 51 - 60 tahun sebesar 51\% dan usia 40 50 tahun sebesar 19\%. Pada kedua kelompok usia antara usia 40-60 tahun dikategorikan usia produktif dalam usahatani kedelai. Pada kelompok usia antara 61 - 70 tahun berjumlah 30\% cenderung menggunakan tenaga upah harian luar keluarga karena keterbatasan tenaga sebagai usia lanjut.

Petani yang pernah mengenyam tingkat pendidikan SMP (41\%) dan SMA (29\%) lebih cenderung kooperatif dalam menerima inovasi teknologi (inotek) baru, sementara tingkat pendidikan SD sebesar 30\% lebih cenderung menonjolkan pengalaman usahataninya sehingga peluang adopsi inovasi lebih lambat.

Petani pada usia 50-60 tahun cenderung memiliki jumlah anggota keluarga 3 - 4 orang sebesar $62 \%$. Sementara keluarga petani yang beranggotakan 5 - 6 orang yang keberadaannya sebesar $27 \%$. Semakin banyak anggota keluarga akan mempengaruhi kesempatan menggunakan tenaga kerja usahatani akan lebih tinggi.

Pengalaman usahatani kedelai akan mempengaruhi aplikasi budidaya kedelai maupun peluang kesuksesan saat panen. Porsentase 32\% ditunjukkan pengalaman tanam kedelai dari 16 - 30 tahun dan > 30 tahun sebesar $7 \%$ pada umumnya merupakan petani mainded komoditas kedelai. Sementara sebesar $61 \%$ memiliki pengalaman usahatani kedelai $<15$ tahun lebih fleksibel dalam melakukan usahataninya, yaitu jika tingkat harga kedelai rendah maka petani tersebut akan berganti usahatani pada komoditas jagung maupun sebaliknya. 


\section{Respon petani pada Peluang Adopsi VUB}

Petani di kabupaten Pasuruan dan Mojokerto telah lama memahami bahwa penggunaan inovasi teknologi (inotek) pada usahatani kedelai sangat terdapat perbedaan yang signifikan atas hasil produksi serta keuntungan yang diperoleh per luasan areal lahan garapannya. Kendala petani dalam adopsi inotek, antara lain: ketersediaan benih bersertifikasi pada musim tanam, keterbatasan modal usahatani, kesulitan membeli pupuk, rendahnya kesadaran petani dalam mengakses informasi inotek kurangnya koordinasi dan bimbingan tentang inotek komoditas kedelai oleh petugas pertanian. Pola tanam dari kedua kabupaten cenderung sama yaitu 1) Padi-PadiKedelai/Jagung, jenis tanah sawah irigasi; dan 2) Padi-Jagung/Kedelai-Jagung, pola tanam ini umumnya pada jenis tanah tadah hujan.

Respon petani dari pengembangan varietas Wilis, Anjasmoro, Devon 1 dan Detap 1, petani lebih menyenangi varietas Detap 1 untuk pengembangan usahatani selanjudnya karena lebih tahan pecah polong, biji besar, dan poduksi tinggi dari tiga varietas lainnya. Respon positip petani pada VUB Detap 1 memiliki beberapa karakter yang sesuai keinginan petani yang ditunnjukkan pada tabel 2.

Tabel 2. Daya Tarik Detap 1 Pengaruhi Alih Inotek pada Usahatani Kedelai

\begin{tabular}{clc}
\hline No. & \multicolumn{1}{c}{ Uraian } & Persentase $(\%)$ \\
\hline 1. & Tahan pecah polong & 23 \\
2. & Produksi Tinggi & 20 \\
3. & Pohon tahan angin tidak mudah roboh & 14 \\
4. & Percabangan Banyak & 14 \\
5. & Umur Panen Pendek & 14 \\
6. & Jumlah Biji/Polong banyak & 7 \\
7. & Warna Kulit Biji Cerah/Mengkilat & 4 \\
8. & Jarak buku pendek/sesuai dengan tinggi tanaman & 4 \\
\hline
\end{tabular}

Karakteristik varietas Detap 1 menjadi acuan petani dalam upaya alih inotek sebelumnya, pendapat petani melihat pertanaman kedelai Detap 1 memiliki kelebihan tahan pecah polong dan produksi tinggi dengan nilai porsentase suka sebesar 20-23\%. Selanjudnya yang disukai petani adalah batangnya kokoh walaupun terkena angin tidak mudah roboh, percabangan banyak, dan umur panen pendek (genjah) dapar nilai $14 \%$. Sementara porsentase $4-7 \%$ menurut petani tidak menjadi nilai daya Tarik utama karena jumlah biji/polong banyak dan jarak buku pendek telah terwakili oleh karakter produksi tinggi diatas. Selanjudnya karakter warna kulit biji cerah mengkilat tetap akan dibeli oleh pedagang pengumpul, yang penting tanaman tidak roboh maupun polong tidak mudah pecah maka biji akan tetap berkualitas baik (biji tidak busuk dilahan).

\section{Kelayakan Usahatani Kedelai}

Penggunaan varietas Wilis, Anjasmoro, Devon 1, dan Detap 1. Tiga varietas Wilis, Anjasmoro, Devon 1 adalah hasil dari benih turunan yang telah ditanam 3-5 kali, jika hasil panen digunakan sebagai benih kembali menyebabkan penurunan mutu dan penurunan kuantitas hasil saat panen. Pada tahun 2019 ada program pengembangan komoditas kedelai varietas Detap 1 benih bersertifikasi/bermutu digunakan sebagai bahan tanam dengan didukung aplikasi teknologi budidaya yang betul dapat terlihat hasil panen yang menguntungkan, walaupun biaya usahataninya lebih tinggi dari tiga varietas turunan/eksisting, pada tabel 3.

Tabel 3. Perbandingan Hasil Keuntungan pada Varietas Bersertifikat dengan Varietas Turunan

\begin{tabular}{lcccccc}
\hline Varietas & $\begin{array}{c}\text { Produktivitas } \\
\text { (ton/ha) }\end{array}$ & $\begin{array}{c}\text { Nilai } \\
\text { Produksi } \\
(\mathrm{Rp})\end{array}$ & $\begin{array}{c}\text { Biaya } \\
\text { Usahatani } \\
(\mathrm{Rp})\end{array}$ & $\begin{array}{c}\text { Keuntungan } \\
\text { Usahatani }\end{array}$ & $\begin{array}{c}\text { Nilai } \\
\text { B/C } \\
\text { ratio }\end{array}$ & $\begin{array}{c}\text { Status bahan } \\
\text { benih tanam }\end{array}$ \\
\hline Wilis & 1,29 & 8.456 .964 & 6.712 .262 & 1.744 .684 & 1,24 & Turunan \\
Anjasmoro & 2,16 & 14.057 .540 & 10.553 .571 & 3.503 .969 & 1,33 & Turunan \\
Devon 1 & 2,15 & 14.137 .648 & 10.553 .571 & 3.584 .077 & 1,23 & Turunan \\
Detap 1 & 2,49 & 16.732 .776 & 11.016 .393 & 5.716 .383 & 1,52 & Bersertifikasi \\
\hline
\end{tabular}

Pada tabel 3 diatas menunnjukkan nilai $\mathrm{B} / \mathrm{C}$ ratio signifikan dengan nilai keuntungan pada penggunaan benih bersertifikat varietas Detap 1 dibandingkan dengan petani yang menggunakan benih turunan varietas Wilis, Anjasmoro, dan Devon 1.

\section{Pemasaran}

Hasil panen kedelai petani secara langsung ditampung oleh pedagang pengumpul setempat yang telah lama bekerja sama dengan kelompok tani. Pembayaran hasil panen dilakukan setelah panenan kedelai petani disetorkan pada pedagang besar dalam kecamatan. Harga kedelai bervariasi tergantung kondisi biji/ose kedelainya, jika biji besar kering bening harga sekitar Rp. 6.800-7.000; biji besar kering sedikit kusam harga 
sekitar Rp. 6.400-6.700; sedangkan biji kecil sedikit kusam harga sekitar Rp.6.000-6.300. Harga hasil panen biji kedelai sesuai grade kualitas warna biji cerah dan ukuran biji kedelai adalah sebagai dasar penentuan harga beli pedagang pengumpul pada petani. Harga biji kedelai varietas Detap 1 pada umumnya harganya masuk pada Rp. 6.800-7.000. Untuk Anjasmoro, Devon 1, Wilis masuk pada grade dan harga Rp. 6.400-6.700. Harga beli biji/ose kedelai tertinggi dari ketiga varietas lainnya saat panen karena varietas Detap 1 memiliki performa baik yaitu bentuknya bulat besar warna kuning cerah.

\section{KESIMPULAN}

1. Penggunaan varietas unggul/brsertifikat sebagai bahan tanam merupakan kunci awal peningkatan produktifitas, peningkatan pendapatan usahatani, dan menumbuhkan ketertarikan petani pada alih inovasi teknologi baru yang lebih menguntungkan.

2. Upaya Gapoktan atau kelompok tani melakukan kerjasama pengadaan benih kedelai bermutu.

3. Daerah sentra kedelai perlu adanya pembinaan/pendampingan serius membentuk satu penangkar kedelai pada wilayah sentra kedelai.

4. Upaya petugas Mantri Pertanian dan PPL dapat membantu mencarikan akses benih kedelai bermutu/bersertifikat sesuai preferensi petani dan pasar pada saat menjelang musim tanam.

5. Pemerintah pusat perlu memberi subsidi harga benih kedelai bersertifikat untuk mewujudkan kenaikan tingkat produktivitas kedelai nasional.

\section{DAFTAR PUSTAKA}

Kune, S.J. 2017. Analisis Pendapatan dan Keuntungan Relatif Usahatani Jagung di Desa Bitefa Kecamatan Miomaffo Timur Kabupaten TTU. Jurnal Agribisnis Lahan Kering. Vol. 2 (2): 23-24.

Manyamsari, I., dan Mujiburrahmad. 2014. Karakteristik Petani Dan Hubungannya Dengan Kompetensi Petani Lahan Sempit. Jurnal Agrisep. Vol 15 (2): 58 - 74.

Noviyanti, S., Kusmiyati., dan Sulistyowati, D. 2020. Adopsi Inovasi Penggunaan Varietas Unggul Baru Padi Sawah (Oryza sativa L.) di Kecamatan Cilaku Kabupaten Cianjur Provinsi Jawa Barat. Jurnal Inovasi Penelitian. Vol. 1 (4): 771 - 782.

Nurwanda, A., dan Badriah, E. 2020. Analisis Program Inovasi Desa Dalam Mendorong Pengembangan Ekonomi Lokal Oleh Tim Pelaksana Inovasi Desa (PID) Di Desa Bangunharja Kabupaten Ciamis. Jurnal Ilmiah Ilmu Administrasi Negara. Vol. 7 (1): 68 -75.

Ridwan, I., Dollo, A., dan Andriyani, A. 2019. Implementasi Pendekatan Participatory Rural Appraisal pada Program Pelatihan. Journal of Nonformal Education and Community Empowerment. Vol. 3 (2): 88 94.

Sekarmurti, P.K., Prastiwi, W.D., dan Roessali, W. 2018. Preferensi Penggunaan Kedelai Pada Industri Tempe dan Tahu Di Kabupaten Pati. Jurnal Sungkai. Vol. 6 (1): 97 - 109. 